\section{4 \\ POLYMORPHISM PROMOTOR GENE OF IL-4 AND IL-4 LEVEL AT GRAVES DISEASE PATIENTS}

R Masri Muchtar. Faculty of Medicine Andalas University Padang Indonesia, Internal Medicine, Padang, Indonesia

\subsection{6/lupus-2017-000215.294}

Background and aims Graves diseases are hyperthyroidism cause by immunological factor. Thyroid antibody at Graves disease activated thyrotropin receptor to make increase of thyroid hormone production. Treatment with prophyltiourasil can decrease the level of thyroid hormone but level of IL-4 are still higher more than normal. Aim of the study to know polymorphism promotor gene of IL-4 and correlation with IL4 level at Graves disease patients.

Methods Study done from 35 Graves disease patients. Blood vena sample take for DNA isolation, thyroid antibody and IL4 level. Polymorphism promotor gene IL-4 with PCR-RFLP using restriction enzyme and electrophoresis by agarose gel $1,5 \%$. Polymorphism promotor gene IL-4 continued with PCR sequencing. Thyroid antibody and IL-4 level was measure by ELISA.

Results Analysis from 35 patients with Graves disease found IL-4 level are 22,77 $\pm 9,43 \mathrm{pg} / \mathrm{ml}$ (normal $<1,3 \mathrm{pg} / \mathrm{ml}$ ). Polymorphism promotor gene IL-4 was found at T-589C and T$34 \mathrm{C}$ position. Polymorphism promotor gene IL-4 at T-589C was found at $28(80 \%)$ sample. Polymorphism promotor gene IL-4 at T-34C was found at $27(77,1 \%)$ sample.This study found relation of polymorphism promotor gene IL-4 with high level of IL-4.

Conclusions IL-4 level are higher at Graves diseases patients. Polymorphism promotor gene IL-4 found at T-589C position $(80 \%)$ and T-34C position (77\%). Suggestion polymorphism promotor gene IL-4 have relation with high level IL-4 at Graves disease patients

\section{CORRELATION BETWEEN SIX MINUTE WALK TEST AND PLASMA PROBNP LEVEL WITH ECHOCARDIOGRAPHIC FINDINGS OF PULMONARY HYPERTENSION IN PATIENTS WITH SYSTEMIC LUPUS ERYTHEMATOUS}

${ }^{1} \mathrm{Z}$ Mirfeizi*, ${ }^{2} \mathrm{~L}$ Ghofraniha, ${ }^{1} \mathrm{~F}$ Seyyedi khabbaz, ${ }^{3} \mathrm{~F}$ Vakilian, ${ }^{4} \mathrm{~S}$ eslami. ${ }^{1}$ mashhad university of medical sciences, Rheumatic disease research centre, Mashhad, Iran; ${ }^{2}$ mashhad university of medical sciences, Lung Disease Research Centre, Mashhad, Iran; ${ }^{3}$ mashhad university of medical sciences, Preventive Atherosclerotic Research Center- Cardiology Department, Mashhad, Iran; ${ }^{4}$ mashhad university of medical sciences, Department of Medical Informatics, Mashhad, Iran

\subsection{6/lupus-2017-000215.295}

Background and Aims:

Aim Pulmonary arterial hypertension (PAH) is an increasingly recognised complication of systemic lupus erythmatous, but may remain underdiagnosed if asymptomatic.

The purpose of this study is to assess correlation of six minute walk test (6WMT) and serum pro-BNP levels with echocardiographic findings of pulmonary arterial hypertension in patients with systemic lupus erythematosus.

Methods This is a prospective cross sectional study of 50 SLE patients using resting transthoracic echocardiography to estimate the systolic pulmonary artery pressure (sPAP).
Results Five out of 50 patients were diagnosed to have PAH with sPAP $>30 \mathrm{~mm} \mathrm{Hg}$ (range $31-40 \mathrm{mmHg}$ ) based on echocardiography. Spirometric parameters also did not show any difference between the two groups $(p>0.05)$, but the difference in total distance walked in six minute and serum proBNP level between SLE patients with and without PAH was considered significant $(p<0.05)$. A high correlation was found between pulmonary artery pressure and serum proBNP level but not between pulmonary artery pressure and the six minute walked distance in SLE patients.

Conclusion The point prevalence of PAH in SLE patients was $10 \%$ in our study and the significant correlation between pulmonary artery pressure and serum proBNP level suggests that it can be used as a valuable marker for early diagnosis of asymptomatic pulmonary hypertension in patients with systemic lupus erythematosus.

\section{CASE SERIES INVOLVING OBSTETRICS EXPERIENCES AND OUTCOMES IN CONNECTIVE TISSUE DISEASE PATIENT IN UNIVERSITI KEBANGSAAN MALAYSIA MEDICAL CENTRE (UKMMC): A SINGLE CENTRE EXPERIENCE}

MS Mohamed Said, JB Eeu, AS Mohamed Yazid, A Chandra, FN Ahmad Yazid, N Abd Aziz, SS Shaharir, KT Chew. Universiti Kebangsaan Malaysia Medical Centre, Medical, Kuala Lumpur, Malaysia

\subsection{6/lupus-2017-000215.296}

Background and aims Connective tissue diseases (CTD) such as systemic lupus erythematosus (SLE), rheumatoid arthritis (RA), antiphospholipid syndrome (APS) and others are likely to be worsening during pregnancy. There are poor pregnancy performances because of the abnormal immune system activity. The aim of the study was to observe the obstetrics experiences and the outcomes.

Methods A retrospective study was done and a total of 58 cases of pregnancy were taken from year 2010-2015 in Universiti Kebangsaan Malaysia Medical Centre (UKMMC).

Results Fifty-eight pregnancies were observed in 44 women where there were fifty pregnancies $(86.2 \%)$ with SLE, 4 (6.9\%) pregnancies with RA and 4 (6.9\%) pregnancies with APS. There were $6(10.3 \%)$ pregnancies in active group and $52(89.7 \%)$ pregnancies in remission group. Among the 58 pregnancies, there were $29(50.9 \%)$ birth with no complication, $9(15.5 \%)$ miscarriages, $8(13.8 \%)$ premature babies, 2 (3.4\%) stillbirth, $1(1.7 \%)$ intrauterine growth restriction, 1 (1.7\%) neonatal death and 7 (12.1\%) others (pre-eclampsia, impending eclampsia, oligohydramnios, chorioamnionitis, persistent urinary tract infection, fetal distress and placenta previa). Rate of live birth is affected by type of CTD $\left(x^{2}=6.520\right.$, $\mathrm{p}=0.038)$ and anti double stranded DNA $\left(\mathrm{x}^{2}=6.157\right.$, $\mathrm{p}=0.021)$. Pregnancy has a significant association with Complement 3 (C3) value $(t=2.003, p=0.05)$.

Conclusions This study showed there is a significant relationship between antidsDNA and type of CTD with pregnancy. C3 value also showed significant changes in pre pregnancy and during pregnancy. 